\title{
THE QUALITY OF PHYSIC NUT (JATROPHA CURCAS L.) SEEDS PACKED IN PLASTIC MATERIAL DURING STORAGE
}

\author{
RANTJE LILLY WORANG ${ }^{1}$ \\ OKKY SETYAWATI DHARMAPUTRA ${ }^{2,3}$ \\ RIZAL SYARIEF ${ }^{4}$ AND MIFTAHUDIN ${ }^{2}$
}

\author{
${ }^{1}$ Faculty of Mathematics and Natural Sciences, Manado State University, \\ Tondano, North Sulawesi, Indonesia \\ ${ }^{2}$ Department of Biology, Faculty of Mathematics and Natural Sciences, \\ Bogor Agricultural University, Darmaga Campus, Bogor, Indonesia \\ ${ }^{3}$ SEAMEO BIOTROP, Jl. Raya Tajur Km. 6, PO Box 116, Bogor, Indonesia \\ ${ }^{4}$ Department of Food Science and Technology, Faculty of Agricultural Technology, \\ Bogor Agricultural University, Darmaga Campus, Bogor, Indonesia
}

\begin{abstract}
The effect of storage duration on fungal population, moisture content, lipid and free fatty acid contents, lipase activity, viability and vigor of physic nut seeds was investigated. Physic nut seeds with initial moisture content of $7.9 \%$ were stored in plastic bags under warehouse conditions. Samples of physic nut were collected before storage, and subsequently after one to six months of storage. The results showed that the moisture contents increased after one month of storage, and became relatively constant up to six months of storage. The range of moisture contents (7.9 8.4\%) was safe for storage of physic nut seeds. Sixteen fungal species were isolated from physic nut seeds during six months of storage. Fungal population decreased with the increase of storage duration. At the beginning of storage, most of the fungi that infected the seeds were classified as field fungi, such as Colletotrichum sp., Cladosporium spp., and Fusarium spp.. Their populations decreased with the increase of storage duration. After three months of storage, the existence of field fungi was generally replaced by storage fungi, such as Aspergillus spp., and Penicillium spp. dominate the population. Lipid contents, viabilities and vigors decreased with the increase of storage duration, while free fatty acids and lipase activities increased. Under uncontrolled conditions, physic nut seeds packed in plastic material can be stored up to one month for seeds to be planted, while it can be stored up to five months for producing oil.
\end{abstract}

Key words : storage duration, fungi, lipid, free fatty acid, lipase, viability, vigor, physic nut, Jatropha curcas L.

Corresponding author : okky@biotrop.org 


\section{INTRODUCTION}

With the increasing demand of fuel products, and the decreasing of fossil fuel sources, the world prices of petrol and diesel are increasing, including in Indonesia. It is assumed, that the fossil fuel reserve will be exhausted within 10 - 15 years in Indonesia. Hence alternative sources of energy for running our generators, automobiles, etc are being considered (Hambali 2006). The possibility of obtaining oil from plant resources to be a supplement or replacement of fossil fuel has aroused a great interest. In several countries including in Indonesia, non-edible vegetable oil can be used as biodiesel, which is a nontoxic and biodegradable oil.

Physic nut (Jatropha curcas L.) seeds is known to be a good source for biodiesel. The oil contents in the seeds and in the kernels are $25-30 \%$ and $50-60 \%$, respectively. The oil contains $21 \%$ saturated fatty acids and $79 \%$ unsaturated fatty acids (Gubitz et al. 1997). Other uses of physic nut extracted oil are for making soap, biopesticide, and medicinal substance for skin disease treatment. The physic nut oil has the requisite potential of providing a promising and commercially viable alternative to diesel oil, since it has desirable physicochemical and performance characteristics comparable to diesel. Cars could be run with physic nut without requiring much change in design (Hambali et al. 2006; Warsiki et al. 2007)

Physic nut seeds can be used as seeds and oil producer. According to Adikadarsih and Hartono (2006) the use of physic nut seeds for seedlings should derive from the fruits which skin is yellow up to blackish yellow in colour, because they have high percentages of viability and vigor, i.e. 89 and $81 \%$, respectively. Wanita and Hartono (2006) reported that seeds originated from physic nut fruits which skin is yellow up to blackish yellow in colour produce seeds with highest oil content, i.e. $28-30 \%$.

To obtain good quality of physic nut seeds, some factors should be taken into consideration, i.e. the degree of fruit maturity, safe seed moisture content, appropriate container and storage condition, duration of storage, good viability and vigor of seeds. Consequently, appropriate postharvest handling is needed.

Christensen and Kaufmann (1969) reported that during storage seeds or grains could be infected by fungi which cause a decrease in viability, discolouration, various biochemical changes, heating and mustiness, loss in weight, and production of toxins when it is consumed may be injurious to human and domestic animals. In many cases, fungi infecting seeds are seed-borne pathogens. They play an important role in the transmission of numerous pathogenic species to seedlings as well as to the soil (Chelkowski 1991).

The objective of this study was to determine the effects of storage duration on fungal population, moisture content, lipid and free fatty acid contents, lipase activity, viability and vigor of physic nut seeds. 


\section{MATERIALS AND METHODS}

\section{Origin of physic nut seeds}

Physic nut seeds were obtained from fresh harvested fruits which fruit skin was yellow up to blackish yellow in colour. The fruits were obtained from plants (Lampung accession) cultivated in Loyang Village, Cikedung Subdistrict, Indramayu Regency, West Java in May 2007.

\section{Fruit peeling and seed drying}

The fruit skins were peeled using a knife, then the seeds were air-dried on the selves in a shaded place up to moisture contents of about $8 \%$.

\section{Packaging and storing of physic nut}

Prior to packaging, damaged seeds were hand picked from the batch. Sound seeds were packed in plastic packaging materials $(2 \mathrm{~kg} / \mathrm{bag})$ under normal oxygen concentration. They were then placed randomly on wooden shelves and stored for one, two, three, four, five and six months (June - November 2007) under warehouse conditions. The composition of the plastic packaging material was NY15/PE15/ LLDPE70. According to Dharmaputra et al. (2007) total fungal population of peanut kernels packed in three different types of plastic packaging materials (OPP30/PE15/ LLDPE80, NY15/PE15/LLDPE80, and NY15/PE15/LLDPE70 ) under low oxygen concentration were not significantly different. The characteristic of plastic packaging material is presented in Table 1 . The plastic packaging bag was produced by PT Interkemas Flexipack in Tangerang, West Java.

Table 1. The characteristics of plastic packaging material

\begin{tabular}{cccccc}
\hline $\begin{array}{c}\text { Name of } \\
\text { product }\end{array}$ & Code & Compositition & $\begin{array}{c}\text { Thickness } \\
(\mathrm{mm})\end{array}$ & $\begin{array}{c}\text { WVTR } \\
\text { (Water Vapour } \\
\text { Transmis- } \\
\text { sion Rate })(\mathrm{g} / \\
\left.\mathrm{m}^{2} / 24 \mathrm{Hrs}\right)\end{array}$ & $\begin{array}{c}\mathrm{O}_{2} \mathrm{TR}(\mathrm{Oxygen} \\
\text { Transmission } \\
\text { Rate })\left(\mathrm{cc} / \mathrm{m}^{2} / 24\right. \\
\mathrm{Hrs})\end{array}$ \\
\hline $\begin{array}{c}\text { TRL.VACUUM } \\
\text { BAG 03 }\end{array}$ & NY70 & $\begin{array}{c}\text { NY 15/PE } \\
\text { 15/LLDPE 70 }\end{array}$ & 0.0974 & 0.6340 & 1.8734 \\
\hline
\end{tabular}

Note: Analyzed by Test and Calibration Laboratory, Institute for Chemical and Packaging, Jakarta, Indonesia

OPP : Oriented Polypropilene

LLDPE : Linear Low Density Polyethylene

The experiment was arranged in completely randomized design. Three replications (= bags) were used for each storage duration (including at the beginning of storage). Each bag was used to pack physic nut seeds with different storage duration and 
replications. The ambient temperature and relative humidity of the storage room were recorded using a tinytag data logger.

\section{Sampling method}

Samples of physic nut seeds were collected from each bag before storage (at the beginning of storage) and subsequently every month thereafter until 6 months of storage. Each sample was divided three times using a box divider to obtain working samples for moisture content, fungal population, lipid and free fatty acid contens, lipase activity, viability and vigor of seeds, and reserved sample.

Determination of moisture content, fungal population, lipid and free fatty acid contens, lipase activity, viability and vigor

Moisture contents of seeds (based on wet basis) were determined using oven method (ISTA 1999, with a slight modification). Two replicates were used for each sample.

Fungi from each sample was isolated and enumerated using serial dilution method followed by pour plate method on Dichloran 18\% Glycerol Agar (DG18) (Hocking and Pitt 1980; Pitt et al. 1992). Fungal identification was conducted based on Samson et al. (1996), Pitt and Hocking (1997) using Czapek Yeast Extract Agar (CYA) and CYA containing 20\% sucrose (CY20S). Lipid and free fatty acid contents were determined based on Soxhlet and titration methods, respectively (AOAC 1999). Lipase activity was determined based on Moore (1973, with a slight modification).

Viability (percentage of germination) of seeds from each sample was determined by growing 25 seeds in rectangular plastic containers containing sand $(5 \mathrm{~kg} /$ container $)$ 7 and 10 days after planting (DAP) under green house conditions (Prihandana and Hendroko 2006). Normal germination was observed 7 DAP, while normal and abnormal germination were observed 10 DAP. Determination of seed vigor from each sample was conducted using rice straw paper method (Sadjad 1994). Vigor, less vigor, non-vigor, and death were observed 7 DAP.

\section{Statistical analysis}

Standard ANOVAs were used to analyse the results followed by Duncan's multiple range test at the $5 \%$ probability level.

\section{RESULTS AND DISCUSSION}

\section{Moisture contents}

Moisture content is the most important environmental factor that influence fungal growth in stored grains (Christensen et al. 1992). Storage duration gave very significant differences on the moisture contents of physic nut seeds. The moisture 
contents of physic nut after one month of storage (8.41\%) were higher and significantly different from those at the beginning of storage (7.89\%). The moisture contents decreased after two, three, four, five, and six months of storage, i.e. 8.14, 8.12, 8.14, 8.06 and $8.16 \%$, respectively (Table 2). According to the Directorate General of Plantation Crop (2006) the safe moisture content for storage of physic nut seeds was $7-9 \%$. The moisture content of grains is in equilibrium with the relative humidity of the storage. Range of temperature and relative humidity are presented in Table 3 . The moisture content of the seeds was correlated with the relative humidity of the storage.

The type of plastic packaging material also affects the moisture contents of physic nut seeds. Plastic packaging bags used in this study are made from good material for storing peanut kernels (Dharmaputra et al. 2007). According to Warsiki et al. (2007) the moisture contents of physic nut seeds packed in bags were higher than those packed in polypropylene bags.

Table 2. Moisture content, total fungal population, lipid and free fatty acid contents, lipase activity, viability and vigor of physic nut seeds during storage

\begin{tabular}{|c|c|c|c|c|c|c|c|}
\hline $\begin{array}{l}\text { Duration } \\
\text { of storage } \\
\text { (month) }\end{array}$ & $\begin{array}{c}\text { Moisture } \\
\text { content } \\
\text { (\% wet } \\
\text { basis) }\end{array}$ & $\begin{array}{l}\text { Total fungal } \\
\text { population } \\
\text { (cfu/g dry } \\
\text { basis) }\end{array}$ & $\begin{array}{c}\text { Lipid } \\
\text { content } \\
\text { (\% dry } \\
\text { basis) }\end{array}$ & $\begin{array}{c}\text { Free } \\
\text { fatty acid } \\
\text { content } \\
\text { ( } \% \text { dry } \\
\text { basis) }\end{array}$ & $\begin{array}{l}\text { Lipase } \\
\text { activity } \\
(\mathrm{U} / \mathrm{ml})\end{array}$ & $\begin{array}{c}\text { Viability } \\
(\%)\end{array}$ & Vigor (\%) \\
\hline 0 & $\begin{array}{c}7.89 \mathrm{a} \pm \\
0.07\end{array}$ & $\begin{array}{c}8589.0 \mathrm{a} \pm \\
1359.3\end{array}$ & $\begin{array}{c}41.2 \mathrm{a} \pm \\
0.34\end{array}$ & $\begin{array}{c}0.10 \mathrm{a} \pm \\
0.01\end{array}$ & $\begin{array}{c}0.23 \mathrm{a} \pm \\
0.08\end{array}$ & $\begin{array}{c}89.33 \mathrm{a} \pm \\
8.33\end{array}$ & $\begin{array}{c}83.33 \mathrm{a} \pm \\
5.77\end{array}$ \\
\hline 1 & $\begin{array}{c}8.41 \mathrm{~d} \pm \\
0.02\end{array}$ & $\begin{array}{c}6519.6 \mathrm{a} \pm \\
3224.5\end{array}$ & $\begin{array}{c}37.9 \mathrm{~b} \pm \\
0.69\end{array}$ & $\begin{array}{c}0.60 \mathrm{~b} \pm \\
0.01\end{array}$ & $\begin{array}{c}0.35 \mathrm{ab} \pm \\
0.03\end{array}$ & $\begin{array}{c}74.67 \mathrm{~b} \pm \\
4.62\end{array}$ & $\begin{array}{c}70.00 \mathrm{~b} \pm \\
0.00\end{array}$ \\
\hline 2 & $\begin{array}{c}8.14 c \pm \\
0.04\end{array}$ & $\begin{array}{c}5917.7 \mathrm{a} \pm \\
1026.8\end{array}$ & $\begin{array}{l}37.2 \mathrm{bc} \\
\pm 0.66\end{array}$ & $\begin{array}{c}0.62 \mathrm{~b} \pm \\
0.01\end{array}$ & $\begin{array}{c}0.42 \mathrm{bc} \pm \\
0.04\end{array}$ & $\begin{array}{c}71.33 \mathrm{bc} \pm \\
1.15\end{array}$ & $\begin{array}{c}63.33 b c \pm \\
5.77\end{array}$ \\
\hline 3 & $\begin{array}{c}8.12 b c \pm \\
0.02\end{array}$ & $\begin{array}{c}1405.4 \mathrm{~b} \pm \\
1196.7\end{array}$ & $\begin{array}{l}35.9 \mathrm{~cd} \\
\pm 0.56\end{array}$ & $\begin{array}{c}0.67 b c \pm \\
0.03\end{array}$ & $\begin{array}{c}0.51 \mathrm{~cd} \pm \\
0.05\end{array}$ & $\begin{array}{c}68.00 \mathrm{bc} \pm \\
2.00\end{array}$ & $\begin{array}{c}56.67 \mathrm{c} \pm \\
5.77\end{array}$ \\
\hline 4 & $\begin{array}{c}8.14 c \pm \\
0.03\end{array}$ & $\begin{array}{c}1297.3 \mathrm{~b} \pm \\
377.2\end{array}$ & $\begin{array}{c}35.1 \mathrm{de} \\
\pm 0.54\end{array}$ & $\begin{array}{c}0.79 \mathrm{c} \pm \\
0.06\end{array}$ & $\begin{array}{c}0.58 \mathrm{~d} \pm \\
0.01\end{array}$ & $\begin{array}{c}64.67 \mathrm{~cd} \pm \\
2.31\end{array}$ & $\begin{array}{c}36.67 \mathrm{~d} \pm \\
5.77\end{array}$ \\
\hline 5 & $\begin{array}{c}8.06 \mathrm{~b} \pm \\
0.02\end{array}$ & $\begin{array}{c}1145.6 \mathrm{~b} \pm \\
761.9\end{array}$ & $\begin{array}{c}33.5 \text { ef } \pm \\
0.86\end{array}$ & $\begin{array}{c}1.00 \mathrm{~d} \pm \\
0.09\end{array}$ & $\begin{array}{c}0.71 \mathrm{e} \pm \\
0.07\end{array}$ & $\begin{array}{c}60.00 \mathrm{de} \pm \\
3.46\end{array}$ & $\begin{array}{c}33.33 \mathrm{de} \pm \\
5.77\end{array}$ \\
\hline 6 & $\begin{array}{c}8.16 c \pm \\
0.03\end{array}$ & $\begin{array}{c}225.4 \mathrm{~b} \pm \\
28.4\end{array}$ & $\begin{array}{c}31.7 \mathrm{f} \pm \\
2.06\end{array}$ & $\begin{array}{c}1.10 \mathrm{~d} \pm \\
0.14\end{array}$ & $\begin{array}{c}0.93 \mathrm{f} \pm \\
0.15\end{array}$ & $\begin{array}{c}53.33 \mathrm{e} \pm \\
2.31\end{array}$ & $\begin{array}{c}26.67 \mathrm{e} \pm \\
5.77\end{array}$ \\
\hline
\end{tabular}

Note: Means followed by the same letter in the same column are not significantly different according to Duncan's Multiple Range Test at the 5\% level $(\mathrm{P}>0.05)$. 
BIOTROPIA VOL.15 NO. 1, 2008

Table 3. Range of temperature and relative humidity during storage

\begin{tabular}{ccccc}
\hline \multirow{2}{*}{$\begin{array}{c}\text { Duration of } \\
\text { storage }(\text { month) }\end{array}$} & \multicolumn{2}{c}{ Temperature $\left({ }^{\circ} \mathrm{C}\right)$} & \multicolumn{2}{c}{ Relative humidity $(\%)$} \\
\cline { 2 - 5 } & Range & Mean & Range & Mean \\
\hline 1 & $24.4-28.3$ & 26.3 & $55.2-82.8$ & 74.1 \\
2 & $25.1-28.7$ & 26.5 & $48.2-70.2$ & 70.2 \\
3 & $25.1-29.1$ & 26.5 & $55.2-78.5$ & 69.4 \\
4 & $25.1-28.3$ & 26.7 & $46.0-80.7$ & 68.1 \\
5 & $25.1-28.7$ & 26.7 & $55.6-82.4$ & 73.1 \\
6 & $24.4-28.3$ & 26.1 & $65.6-85.4$ & 76.5 \\
\hline
\end{tabular}

According to Desai (2004) modern packaging materials and methods maintain seeds at their original quality from the time of their packaging to the time they are used for planting. The best way to maintain the viability and vigor of many kinds of seeds is to store them in a dry and cold place. Packages designed to protect most physical qualities of seeds, such as weight, size, colour, moisture content, and purity (freedom from weeds, inert matter, disease organisms and damage), as well as their physiological aspects, like viability, vigor and dormancy, are made up of materials that have sufficient tensile strength, bursting strength, and tearing resistance to withstand normal pressures and handling procedures. Polyethylene is the most extensively used thermoplastic film. Conventional low-density films are generally used in seed packages. This packaging material is ideal for providing seale-storage conditions in a humid climate, giving protection against high humidity in a seed store.

\section{Fungal population}

Sixteen fungal spesies were isolated during six months of storage (Table 4). They were Aspergillus flavus, $A$. niger, $A$. ochraceus, $A$. penicillioides, $A$. restrictus, $A$. tamarii, A.wentii, Cladosporium sp., C. cladosporioides, Colletotricum sp., Eurotium chevalieri, E .rubrum, Fusarium moniliforme, F. semitectum, Penicillium citrinum, and P. oxalicum. Aspergillus flavus, A. niger, Cladosporium sp., F. moniliforme, F. semitectum, and P. citrinum were always isolated during storage.

Table 4. Fungal population of physic nut seeds during storage

\begin{tabular}{llrrrrrrr}
\hline & & \multicolumn{7}{c}{ Fungal population (cfu/g dry basis) } \\
\cline { 3 - 9 } No. & \multicolumn{1}{c}{ Fungi } & 0 & 1 & 2 & 3 & 4 & 5 & 6 \\
\cline { 3 - 8 } & & 6.5 & 1.1 & 6.5 & 88.2 & 8.7 & 17.4 & 9.8 \\
\hline 1 & Aspergillus flavus & 3.3 & 2.2 & 4.4 & 3.3 & 1.1 & 2.2 & 3.3 \\
2 & A. niger & 0.0 & 0.0 & 1.1 & 0.0 & 0.0 & 0.0 & 0.0 \\
3 & A. ochraceus & 0.0 & 0.0 & 0.0 & 0.0 & 0.0 & 730.9 & 92.6 \\
4 & A. penicillioides & 0.0 & 50.2 & 61.0 & 0.0 & 695.6 & 0.0 & 0.0 \\
5 & A. restrictus & & & & & &
\end{tabular}


The quality of physic nut (Jatropha curcas L.) - R.L. Worang et al.

Table 4. Continued

\begin{tabular}{|c|c|c|c|c|c|c|c|c|}
\hline \multirow{3}{*}{ No. } & \multirow{3}{*}{ Fungi } & \multicolumn{7}{|c|}{ Fungal population (cfu/g dry basis) } \\
\hline & & \multicolumn{7}{|c|}{ Duration of storage (month) } \\
\hline & & 0 & 1 & 2 & 3 & 4 & 5 & 6 \\
\hline 6 & A. tamarii & 2.2 & 1.1 & 2.2 & 0.0 & 1.1 & 1.1 & 1.1 \\
\hline 7 & A. wentii & 1.1 & 1.1 & 2.2 & 4.4 & 2.2 & 0.0 & 0.0 \\
\hline 8 & Cladosporium sp. & 427.7 & 462.9 & 90.4 & 37.0 & 20.7 & 44.6 & 17.4 \\
\hline 9 & C. cladosporioides & 169.4 & 41.5 & 47.9 & 21.8 & 0.0 & 0.0 & 15.2 \\
\hline 10 & Colletotrichum sp. & 5609.6 & 1880.1 & 1415.2 & 68.6 & 61.0 & 0.0 & 0.0 \\
\hline 11 & Eurotium chevalieri & 0.0 & 0.0 & 0.0 & 1.1 & 0.0 & 0.0 & 2.2 \\
\hline 12 & E. rubrum & 0.0 & 0.0 & 0.0 & 2.2 & 0.0 & 63.1 & 3.3 \\
\hline 13 & $\begin{array}{l}\text { Fusarium monili- } \\
\text { forme }\end{array}$ & 1652.4 & 3703.5 & 580.2 & 1007.8 & 409.3 & 156.6 & 15.2 \\
\hline 14 & F. semitectum & 247.5 & 10.9 & 209.0 & 14.1 & 3.3 & 6.5 & 3.3 \\
\hline 15 & $\begin{array}{l}\text { Penicillium citri- } \\
\text { num }\end{array}$ & 276.8 & 291.5 & 3496.6 & 156.7 & 94.7 & 124.0 & 63.2 \\
\hline 16 & P. oxalicum & 193.2 & 73.2 & 0.0 & 0.0 & 0.0 & 0.0 & 0.0 \\
\hline & Total & 8589.7 & 6519.3 & 5916.6 & 1405.1 & 1297.6 & 1146.4 & 226.5 \\
\hline
\end{tabular}

Duration of storage gave very significant differences on total fungal population. Total fungal population after one, two, three, four, five and six months of storage did not coincide with moisture contents at the same months (Table 2 ). Total fungal population decreased with the increase of storage duration. Total fungal population at the beginning of storage $(8589.0 \mathrm{cfu} / \mathrm{g} . \mathrm{db})$ was higher and significantly different from that after six months of storage $(225.4 \mathrm{cfu} / \mathrm{g} . \mathrm{db})$.

The highest total fungal population was found at the beginning of storage, because the high population of field fungi, such as Cladosporium spp., Colletotricum sp., F. moniliforme, and F. semitectum . Cladosporium spp. produces abundant conidia. Storage fungi found in physic nut seeds were species of Aspergillus and Penicillium. Based on their occurrence in the seeds, Christensen and Kaufmann (1969) divided two groups of fungi that cause deterioration of seeds, i.e. field fungi and storage fungi.

It was assumed that the decrease of fungal population during storage was due to the low of moisture contents in the seeds after one month up to six months of storage. In general the dominant fungal species during storage was field fungi. According to Sauer et al. (1992) fields fungi have high water requirements for their growth, compared to storage fungi.

It was also assumed that the decrease of total fungal population was due to the decrease of oxygen during storage. According to Moore-Landecker (1996) most fungi are obligate aerobes and require at least some free molecular oxygen in the atmosphere. Physic nut seeds also need $\mathrm{O}_{2}$ found in plastic packaging bags for their life. Garraway and Evans (1984) concluded that the type of response by fungi to oxygen concentration depends on the species. 
BIOTROPIA VOL. 15 NO. 1, 2008

\section{Lipid contents}

Storage duration gave very significant differences on lipid contents of physic nut seeds. The lipid contents decreased with the increase of storage duration (Table 2). After one month of storage, lipid contents $(37.9 \% \mathrm{db})$ were lower and significantly different from those at the beginning of storage $(41.2 \% \mathrm{db})$. After six months of storage, lipid contents $(31.7 \% \mathrm{db})$ were lower and significantly different from those at the beginning of storage $(41.2 \% \mathrm{db})$, after one $(37.9 \% \mathrm{db})$, two $(37.2 \% \mathrm{db})$, three $(35.9 \% \mathrm{db})$, and four $(35.1 \% \mathrm{db})$ months of storage.

Physic nut seeds contain high lipid content. The lipid contents in the seeds and in the kernels are $25-30 \%$ and $50-60 \%$, respectively. The lipid contains $21 \%$ saturated fatty acids and 79\% unsaturated fatty acids (Gubitz et al. 1997). Lipid contents of physic nut used in this study were high (37.95\%), because the seeds were derived from fruits which fruit skin is yellow up to blackish yellow. Although after five months of storage lipid contents $(33.5 \% \mathrm{db})$ were significantly different from those at the beginning of storage $(41.2 \% \mathrm{db})$, they were still able to be used for producing oil.

Lipid contents are affected by the degree of fruit maturities at the time of harvesting. Wanita and Hartono (2006) reported that the lowest (10.93\%) and the highest $(29.38 \%)$ lipid contents were found in physic nut seeds derived from fruits which fruit skins are green and yellow, respectively.

\section{Free fatty acid contents and lipase activity}

Due to hydrolysis process, fat and lipid in seeds are broken down into free fatty acids (FFA) and glycerol by lipases. Rapid increases in concentrations of FFA frequently are observed in deteriorating seeds, particularly when the temperature and moisture content are high. Many field and storage fungi produce lipases. Seeds also produce lipases, but these commonly are produced during germination, and are not present in stored seeds (Pomeranz 1992).

Storage duration gave very significant differences on FFA contents of physic nut seeds. FFA contents increased with the increase of storage duration (Table 2). After one month of storage, FFA contents $(0.60 \% \mathrm{db})$ was higher and significantly different from those at the beginning of storage $(0.10 \mathrm{db} \%)$. After five $(1.00 \% \mathrm{db})$ and six months of storage $(1.10 \% \mathrm{db})$ FFA contents were higher and significantly differents from those at the beginning of storage $(0.10 \% \mathrm{db})$, after one $(0.60 \% \mathrm{db})$, two $(0.62 \% \mathrm{db})$, three $(0.67 \% \mathrm{db})$, and four months of storage $(0.79 \% \mathrm{db})$. According to St. Angelo and Ory (1983) lipase and lipoksigenase are important enzymes to degrade lipid in seeds.

Storage duration gave very significant differences on lipase activity of physic nut seeds. Lipase activity increased with the increase of storage duration (Table 2). After two months of storage, lipase activity $(0.42 \mathrm{U} / \mathrm{ml})$ was higher and significantly different from those at beginning of storage $(0.23 \mathrm{U} / \mathrm{ml})$. After five and six months of storage lipase activity $(0.71$ and $0.93 \mathrm{U} / \mathrm{ml}$, respectively) were higher and significantly different 
The quality of physic nut (Jatropha curcas L.) - R.L. Worang et al.

from those at the beginning of storage. After six months of storage, lipase activity was higher and significantly different from those after five months of storage. As the moisture contents were considered low (Table 2) and the total fungal population decreased (Table 4) during storage, the lipase activity could be due to seed enzymes rather than fungal enzymes.

\section{Seed viability and vigor}

According to Pomeranz (1992) fungal infection can decrease seed viability and vigor of seeds during storage. Priestley (1986) reported that the most obvious, though not the most informative, indication of the quality of a seed lot is its germinability. The speed of germination, which has long been recognized as an indicator of seed vigor, is usually a more sensitive measure of seed deterioration than loss of viability.

Storage duration gave very significant differences on the percentages of germination and vigor. The percentages of germination and vigor decreased with the increase of storage duration (Table 2). The percentages of germination after one month of storage (74.67\%) were lower and significantly different from those at the beginning of storage (89.33\%). Directorate General of Estate Crops (2006) determined the germination of physic nut seeds to be planted should be more than $80 \%$. After one month of storage, the percentage of germination $(74.67 \%)$ was significantly different from those at the beginning of storage (89.33\%). Nevertheless, based on statistical analyses, the percentage of germination after one month of storage was $74.67 \pm 4.62 \%$. Consequently, under uncontrolled conditions, physic nut seeds packed in plastic material can be stored up to one month for seeds to be planted. After six months of storage, the percentages of germination (53.33\%) were lower and significantly different from those at the beginning of storage (89.33). According to Copeland and Mc Donald (2001) seeds containing high lipid content decrease their viability faster compared to those containing high carbohydrate content. The seed germination percentage in this study was more than $80 \%$, because the seeds were derived from fruits which fruit skin is yellow up to blackish yellow in colour as required for good quality of physic nut seeds.

The percentages of vigor after one month of storage (70.00\%) were lower and significantly different from those at the beginning of storage (83.33\%). After six months of storage, the percentages of vigor $(26.67 \%)$ were lower and significantly different from those at the beginning of storage $(83.33 \%)$, after one $(70.00 \%)$, two $(63.33 \%)$, three $(56.67 \%)$ and four months $(36.67 \%)$ of storage.

According to Adikadarsih and Hartono (2006) the lowest percentages of germination $(7 \%)$ and vigor $(4.33 \%)$ were found in physic nut seeds derived from fruits which fruit skin is green in color ; while the highest percentage of germination $(91.67 \%)$ and vigor $(84.67 \%)$ were found in seeds derived from fruits with fruit skin is yellow in color. 
Under conditions that favour them to grow, storage fungi invade the germs or embryos of seeds prefentially, and sometimes exclusively. Very often, and especially if the moisture content of the seeds is at or just slightly above the lower limit that allow a given species of storage fungi to grow, the germs may be invaded to the point of near decay, with no evidence of molding being evident outwardly, even with microscopic examination, and little or no invasion of the endosperm immediately adjacent to the germ. The first effect of this invasion is weakening of the germ, followed by death (Sauer et al. 1992).

\section{CONCLUSIONS}

Duration of storage affected the quality of physic nut seeds. After one month of storage, the moisture content of physic nut seeds increased, and became relatively constant up to six months of storage. During storage the moisture contents were still safe for storing physic nut seeds $(7.89-8.41 \%)$.

Sixteen mould species were isolated from physic nut seeds during six months of storage. Fungal population decreased with the increase of storage duration. At the beginning of storage most of fungi infected the seeds were field fungi (Colletotrichum sp., Cladosporium spp., and Fusarium spp.). Their populations decreased with the increase of storage duration and replaced by storage fungi (Penicillium spp. and Aspergillus spp.).

Lipid contents, viabilities and vigors decreased with the increase of storage duration, while free fatty acids and lipase activities increased. Under uncontrolled conditions, physic nut seeds packed in plastic material can be stored up to one month for seeds to be planted, while for producing oil, they can be stored up to five months.

\section{ACKNOWLEDGEMENTS}

The authors gratefully acknowledge Dr. Theresia Prawitasari $\dagger$ for her suggestions and encouregement. We also thank to the staff member of Plant Pathology and Service Laboratory, SEAMEO BIOTROP, who have in one way or another contributed to this research.

\section{REFERENCES}

Adikadarsih, S. \& J. Hartono. 2006. Pengaruh Kemasan Buah terhadap Mutu Benih Jarak Pagar (Jatropha curcas L). Paper presented at Lokakarya II: Status Teknologi Tanaman Jarak Pagar. Pusat Penelitian dan Pengembangan Perkebunan, Departemen Pertanian. Bogor, 29 November 2006. 
The quality of physic nut (Jatropha curcas L.) - R.L. Worang et al.

AOAC. 1999. In Horwits W (ed). Vol. II. Official Methods of Analysis of Food Composition; Additives; Natural Contaminants. 16th ed. Association of Official Analytical Chemist, Gaithersburg.

Chelkowski, J. 1991. Fungal Pathogens Influencing Cereal Seed Quality at Harvest. In Chelkowski, J. (ed.). pp. 53 - 66. Cereal Grain; Mycotoxins, Fungi and Quality in Drying and Storage. Elsevier, Amsterdam.

Christensen, C.M. and H.H. Kaufmann. 1969. Grain Storage: The Role of Fungi in Quality Loss. University of Minnesota Press, Minneapolis.

Christensen, C.M., B.S. Miller and J.A.Johnston. 1992. Moisture and Its Measurement. In Sauer, D.B. (ed.). pp. 39 - 54. Storage of Cereal Grains and Their Products. American Association of Cereal Chemists. Inc., St. Paul.

Copeland, L.O. and M.B. Mc Donald.2001. Principles of Seed Science and Technology. 4th ed. Kluwer Academic Publishers, Boston.

Desai, B.B. 2004. Seeds Handbook; Biology, Production, Processing, and Storage. 2nd ed. Marcel Dekker, Inc., New York.

Dirjenbun. 2006. Pedoman Mutu Benih Jarak Pagar Sistem dan Prosedur Pembangunan Sumber Benih dan Peredaran Benih Jarak Pagar. Direktorat Jenderal Perkebunan, Jakarta.

Dharmaputra, O.S., I. Retnowati and S. Ambarwati. 2007. Three different types of plastic packaging materials: their effects on mould infection and aflatoxin contamination. Biotropia 14(1): 9 - 23.

Garraway, M.O. and R.C. Evans . 1984. Fungal Nutrition and Physiology. John Willey \& Sons, New York.

Gubitz, G.M, M. Mittelbach and M. Trabi. 1999. Exploitation of the Tropical Oil Seed Plant Jatropha curcas L. Bioresource Technology 67 : 73-82.

Hambali, E. 2006. Proses Pengembangan Tanaman Jarak Pagar untuk Biodisel dan Produk Turunan Lainnya. Paper presented at Workshop Pendirian Kebun Bibit Sumber, Demplot dan Feasibility Study untuk Perkebunan Jarak Pagar. Bogor, 16-17 May 2006. SBRC, LPPM-IPB.

Hambali, E. et al. 2006. Jarak Pagar Tanaman Penghasil Biodisel. Penebar Swadaya, Jakarta.

Hocking, A.D. and J.I.Pitt.1980. Dichloran-glycerol medium for enumeration of xerophilic fungi from low-moisture foods. Applied Environmental Microbiology 39 : 488-492.

ISTA. 1999. International Rules for Seed Testing. Proceedings International Seed Testing Association 31 (1), Wageningen.

Moore, T.C. 1973. Research Experiences in Plant Physiology. A laboratory manual. SprigerVerlag, New York.

Moore - Landecker, E. 1996. Fundamental of the Fungi. 4th ed. Prentice - Hall, Inc, New Jersey.

Pitt,J.I.,A.D. Hocking, R.A. Samson and A.D. King.1992. Recommended methods for mycological examination of foods. In Samson, R.A., A.D. Hocking, J.I. Pitt and A.D. King, eds. Pp. 365-368. Modern Methods in Food Mycology. Elsevier, Amsterdam. 
BIOTROPIA VOL. 15 NO. 1, 2008

Pitt, J.I. and A.D. Hocking. 1997. Fungi and Food Spoilage. Blackie Academic \& Professional, London.

Pomeranz, Y.1992. Biochemical, functional and nutritive changes during storage. In Sauer, D.B. (ed.). pp. 55 - 141. Storage of Cereal Grains and Their Products. 4th ed. American Association of Cereal Chemists, Inc., St Paul.

Priestley, D.A. 1986. Seed Aging; Implications for Seed Storage and Persistence in the Soil. Comstock Publishing Associates, Cornell University Press, Ithaca.

Prihandana, R. and R. Hendroko. 2006.Petunjuk Budidaya Jarak Pagar. PT Agromedia Pustaka, Jakarta.

Sadjad, S. 1994. Kuantifikasi Metabolisme Benih. PT Gramedia Widiasarana Indonesia, Jakarta.

Samson, R.A., E.S. Hoeksttra, J.C. Frisvad and O. Filtenborg. 1996. Introduction to Food-borne Fungi. 3th ed. Centraalbureau voor Schimmelcultures, Baarn.

Sauer, D.B., R.A. Meronuck and C.M. Christensen. 1992. Microflora. In Sauer, D.B. (ed.). pp. 313 - 340. Storage of Cereal Grains and Their Products. 4th ed. American Association of Cereal Chemists, Minnesota.

St. Angelo A.J. and R.L. Ory. 1983. Lipid degradation during seed deterioration. Phytopathology 73: 315 .

Wanita, Y.P. and J. Hartono. 2006. Pengaruh Tingkat Kemasakan Buah terhadap Kadar Minyak Jarak Pagar (Jatropha curcas L.) (The Effect of Degree of Fruit Maturity on Oil Content of Jatropha curcas L). Paper presented at Lokakarya II: Status Teknologi Tanaman Jarak Pagar. Pusat Penelitian dan Pengembangan Perkebunan, Departemen Pertanian. Bogor, 29 November 2006.

Warsiki, E., D. Sumangat and W Rismawati. 2007. Pengaruh bahan dan kondisi pengemasan terhadap mutu biji jarak pagar. Paper presented at Konferensi Jarak Pagar Menuju Bisnis Jarak Pagar yang Feasible. SBRC, LPPM, Institut Pertanian Bogor, Bogor, 19 June 2007. 